УДК 347.23

DOI https://doi.org/10.32849/2663-5313/2021.2.04

\title{
Ангеліна Ходирєва,
}

аспірант кафедри щивільно-правових дисииплін

Національної академії внутрішніх справ

\section{ЗВЕРНЕННЯ СТЯГНЕННЯ НА МАЙНО, ПЕРЕДАНЕ В ДОВІРЧУ ВЛАСНІСТЬ: ОКРЕМІ ПИТАННЯ}

Стаття присвячена дослідженню проблематики звернення стягнення на майно, передане в довірчу власність. Наголошується на недосконалості змісту законодавчих норм, які регулюють проиедуру звернення стягнення на об'єкт довірчої власності, що зумовило виникнення проблем як наукового, так і практичного характеру, які продовжують залишатися невирішеними.

Досліджуються теоретичні та практичні проблеми звернення стягнення на майно, передане в довірчу власність. Детально аналізується положення чинного иивільного законодавства, яке регулює порядок звернення стягнення на об'єкт довірчої власності. Висвітлюються прогалини в иивільному законодавстві, пов'язані зі зверненням стягнення на майно, передане в довірчу власність. Піддається критиці законодавчий підхід до формулювання «звернення стягнення на об'єкт довірчої власності». Акиентується увага на невідповідності основним приниипам иивільного законодавства строків, установлених законодавием для звернення стягнення на об'єкт довірчої власності.

Обгрунтована мета застосування такого способу забезпечення виконання зобов'язання, як довірча власність. Наголошується на недосконалості передбаченого иивільним законодавством порядку звернення стягнення на об'єкт довірчої власності. Звертається увага на суттєве порушення балансу інтересів сторін у правовідносинах довірчої власності. Особлива увага приділяється проблемам досягнення й збереження балансу інтересів між довірчим засновником і довірчим власником, кредитором і боржником. Також аналізуються проблеми, з якими кредиторам доведеться зіткнутися в разі звернення стягнення на майно, передане в довірчу власність, у випадках застосування інших способів забезпечення виконання зобов'язання - таких, як застава й іпотека.

Робиться висновок, що правове регулювання прочедури звернення стягнення на об'єкт довірчої власності потребує подальшого законодавчого вдосконалення. Розроблено пропозииї щодо внесення змін до чинного иивільного законодавства, яке регулює питання звернення стягнення на майно, передане в довірчу власність.

Ключові слова: довірча власність, правовідносини довірчої власності, спосіб забезпечення виконання зобов'язання, довірчий засновник, довірчий власник, договір про встановлення довірчої власності, договір купівлі-продажу, кредитор, боржник.

Постановка проблеми. Неналежне виконання боржником взятого на себе зобов'язання завжди було й залишається ключовою проблемою в правовідносинах між кредитором і боржником. Негативним наслідком такого неналежного виконання зазвичай стає звернення стягнення на майно боржника. На відміну від інших способів забезпечення виконання зобов'язання, зокрема застави, іпотеки, довірча власність дає кредитору можливість звернути стягнення на майно боржника без рішення суду. Зважаючи на це, особливого значення набуває звернення стягнення на майно, передане в довірчу власність.

Необхідно також констатувати, що станом на сьогодні відсутне належне законодавче регулювання процедури звернення стягнення на об'єкт довірчої власності. Водночас недосконалість змісту законодавчих норм породжує проблеми як наукового, так i практичного характеру, які продовжують залишатися невирішеними. 3 огляду на це, убачається за необхідне сформулювати низку теоретичних висновків із формуванням на цьому підгрунті пропозицій щодо подальшого вдосконалення процедури звернення стягнення на об'єкт довірчої власності в цивільному праві України.

Довірча власність (траст) є предметом значної кількості правових досліджень і розробок, зокрема праці відповідним питанням присвятили такі зарубіжні та вітчизняні вчені: Г.В. Буяджи, А.С. Генкін, Р.А. Майданик, Р.Л. Наришкіна, К.Г. Некіт, С.О. Сліпченко, Н.В. Фунтікова, Г.Г. Харченко та інші. Проте питання звернення стягнення на майно, передане в довірчу власність, досі залишається поза увагою науковців. 
Метою статті $€$ вивчення стану дотримання балансу інтересів довірчого засновника, який водночас є боржником за основним зобов'язанням, і довірчого власника як кредитора за основним зобов'язанням унаслідок звернення стягнення на майно, передане в довірчу власність, з метою вироблення рекомендацій щодо вдосконалення передбаченої чинним цивільним законодавством процедури звернення стягнення на об'єкт довірчої власності.

Виклад основного матеріалу. Цивільний кодекс України (далі - ЦК України) передбачає право довірчого власника звернути стягнення на об'єкт довірчої власності в разі прострочення виконання боржником як основного зобов'язання, так і його частини. Убачається, що формулювання «звернути стягнення на об'єкт довірчої власності», яке закріплено в ч. 1 ст. $597^{6}$ ЦК України, $\epsilon$ не зовсім юридично коректним, адже саме довірчий власник, який водночас є кредитором за основним зобов'язанням, є власником заставленого майна. Унаслідок цього виникає питання: чи може власник звернути стягнення на власне майно? На нашу думку, більш доречним видається формулювання «довірчий власник має право відчужити об’єкт довірчої власності відповідно до процедури, передбаченої законом або договором про встановлення довірчої власності».

Необхідно констатувати, що найбільшим недоліком процедури звернення стягнення на об'єкт довірчої власності є положення ст. $597^{6}$ ЦК України. Відповідно до ч. 1 ст. $597^{6}$ ЦК України, у разі прострочення виконання боржником основного зобов'язання довірчий власник має право звернути стягнення на об'єкт довірчої власності за умови, що строк прострочення перевищує 20 календарних днів. Крім того, згідно з ч. 1 ст. $597^{6}$ ЦК України, у разі прострочення боржником виконання частини основного зобов'язання довірчий власник має право звернути стягнення на об'єкт довірчої власності, якщо прострочення виконання боржником основного зобов'язання триває більше ніж 30 календарних днів. Із таким підходом законодавця щодо встановлення строків важко погодитися. Звернення стягнення на майно, передбачене ч. 1 ст. $597^{6}$ ЦК України, відбуватиметься в найкоротший термін, незважаючи на те що вищезазначені строки $є$ недостатніми для виконання боржником як основного зобов'язання, так і його частини, що є неприпустимо, адже це ставитиме боржника в украй невигідне становище порівняно з кредитором.

Акцентуємо увагу на тому, що метою забезпечення будь-якого зобов'язання $є$ стимулювання боржника до його належ- ного виконання, тоді як метою звернення стягнення на об'єкт довірчої власності є саме відшкодування майнової шкоди, завданої довірчому власнику як кредитору внаслідок невиконання боржником свого основного зобов'язання, а не збагачення кредитора шляхом набуття майна у власність чи отримання додаткового прибутку внаслідок звернення стягнення на нього. Як слушно зазначає О.В. Манжосова, «довірчий власник здійснює право власності на об'єкт довірчої власності лише для належного виконання забезпеченого нею вимоги (у вигляді непогашеного зобов'язання) або досягнення іншої визначеної мети, яка обтяжує право довірчої власності. Довірчий власник має право здійснити відчуження довірчої власності, передати її в заставу або накласти інші речові обтяження лише для досягнення за їі допомогою визначеної установником мети, або якщо забезпечуване нею зобов'язання не буде виконане належним чином, а з вирученої суми неможливо погасити забезпечувану вимогу, якщо інше не визначено договором або законом» [2, с. 146-147].

3 огляду на вищевикладене, ми вважаємо, що процедура звернення стягнення на об'єкт довірчої власності може бути розпочата довірчим власником не раніше, ніж після закінчення такого строку, який відповідатиме справедливості, добросовісності й розумності як основоположним принципам цивільного законодавства. У зв'язку з цим пропонуємо внести зміни до ч. 1 ст. $597^{6}$ ЦК України, збільшивши строк прострочення виконання боржником основного зобов'язання до двох місяців, а також збільшивши строк прострочення виконання боржником частини основного зобов'язання до трьох місяців.

Відповідно до ч. 2 ст. $597^{6}$ ЦК України, договором, яким установлена довірча власність або на підставі якого виникло основне зобов'язання, можуть бути встановлені інші підстави, з настанням яких у довірчого власника виникає право звернути стягнення на об'єкт довірчої власності. Зауважимо, що законодавець жодним чином не врегульовує питання мінімальних строків для звернення стягнення на об'єкт довірчої власності за підставами, які можуть передбачатися договором про встановлення довірчої власності або основним договором. Для недопущення зловживання кредитором своїми правами необхідно, щоб такі строки, як і строки, які передбачені ч. 1 ст. $597^{6}$ ЦК України, відповідали таким основоположним принципам цивільного законодавства, як справедливість, добросовісність і розумність, і не могли бути меншими, ніж ті, які передбачені 
в ч. 1 ст. $597^{6}$ ЦК України. Унаслідок цього пропонуємо зробити відповідні застереження в ч. 2 ст. $597^{6}$ ЦК України.

Згідно з ч. 3 ст. $597^{6}$ ЦК України, якщо боржник не виконує рішення довірчого власника про дострокове виконання основного зобов'язання протягом 30 календарних днів 3 моменту отримання такого повідомлення (якщо інший строк не встановлено договором), довірчий власник має право звернути стягнення на об'єкт довірчої власності. Убачається, що строк, установлений ч. 3 ст. $597^{6}$ ЦК України, є занадто стислим для дострокового виконання боржником основного зобов'язання, що є неприпустимо. До того ж передбачена ч. 3 ст. $597^{6}$ ЦК України можливість установити в договорі менший строк дострокового виконання основного зобов'язання призведе до порушення балансу інтересів сторін і зловживання кредитором своїми правами.

Зауважимо, що строк для дострокового виконання боржником основного зобов'язання повинен установлюватися відповідно до принципів справедливості, добросовісності й розумності. 3 огляду на вищевикладене, пропонуємо внести зміни до ч. 3 ст. $597^{6}$ ЦК України, збільшивши законодавчо визначений строк дострокового виконання основного зобов'язання до двох місяців і доповнивши ії застереженням щодо того, що договір не може встановлювати менший строк для звернення стягнення на об’єкт довірчої власності внаслідок невиконання боржником рішення довірчого власника про дострокове виконання основного зобов'язання, ніж той, який передбачений цією частиною.

Щодо встановленої ч. 3 ст. $597^{6}$ ЦК України необхідності повідомлення боржника про рішення довірчого власника про дострокове виконання основного зобов'язання зауважимо, що чинне цивільне законодавство не врегульовує питання ні щодо форми такого повідомлення, ні щодо способу його направлення боржнику. Така законодавча невизначеність зі свого боку спричинює неправильне трактування та різне правозастосування положень ч. 3 ст. $597^{6}$ ЦК України.

Положення ст. $597^{8}$ ЦК України, яка регулює порядок звернення стягнення на об'єкт довірчої власності, також потребує суттєвого доопрацювання. Необхідно зауважити, що ще на етапі прийняття Закону України «Про внесення змін до деяких законодавчих актів України щодо стимулювання інвестиційної діяльності в Україні» від 20.09.2019 (далі Закон) [3] Головне науково-експертне управління Апарату Верховної Ради України у висновку від 06.09.2019 вказало, що управ- ління не вбачало необхідності в установленні окремої процедури стягнення на об'єкт довірчої власності, як це передбачено законом [4]. Проте, незважаючи на необхідність законодавчого вдосконалення порядку звернення стягнення на об'єкт довірчої власності, 3 таким висновком важко погодитися.

Детально розглянемо порядок звернення стягнення на об'єкт довірчої власності, закріплений ст. $597^{8}$ ЦК України. Частина 1 ст. $597^{8}$ ЦК України передбачає обов'язок довірчого власника письмово повідомити боржника, користувача та довірчого засновника про свій намір укласти договір купівлі-продажу та мінімальну ціну продажу не пізніше ніж за 30 днів до укладення цього договору. Зауважимо, що вищевказаного строку буде недостатньо для того, щоб боржник, який водночас є довірчим засновником, дійсно зміг заздалегідь до укладення договору купівлі-продажу об'єкта довірчої власності отримати відповідне письмове повідомлення, прийняти рішення щодо придбання майна, переданого в довірчу власність, і вжити заходів, спрямованих на його придбання. Уважаємо, що вищезазначений підхід законодавця щодо визначення строків письмового повідомлення боржника, користувача та довірчого засновника також суперечить основоположним принципам цивільного законодавства (справедливості, добросовісності й розумності), на яких повинні базуватися всі без винятку цивільноправові відносини.

Необхідно також зазначити, що ч. 1 ст. $597^{8}$ ЦК України передбачено обов'язок довірчого власника відшкодувати боржнику, користувачу та довірчому засновнику завдані збитки в разі невиконання вимоги про письмове повідомлення боржника, користувача та довірчого засновника про укладення договору купівлі-продажу об'єкта довірчої власності. Проте, незважаючи на це, можливість зловживання кредитором своїм правом звернути стягнення на об'єкт довірчої власності залишається, що $\epsilon$ неприпустимим. До того ж запровадження вищевказаного обов'язку не зможе запобігти майбутнім негативним наслідкам для боржника, користувача та довірчого засновника. Отже, боржник у будь-якому випадку залишиться в украй невигідному становищі порівняно з кредитором.

Законодавець доречно передбачив у ч. 2 ст. $597^{8}$ ЦК України право боржника (користувача, довірчого засновника) придбати об'єкт довірчої власності. Проте, на нашу думку, установлення п'ятиденного строку 3 дня отримання повідомлення, зазначеного в ч. 1 ст. $597^{8}$ ЦК України, на 
письмове повідомлення довірчого власника про намір боржника (користувача, довірчого засновника) придбати об'єкт довірчої власності й унесення грошової суми в розмірі мінімальної ціни продажу такого об’єкта, повідомленої довірчим власником, на депозит нотаріуса, є невиправдано малим. Крім того, зауважимо, що після прийняття в першому читанні Проекту вищезгаданого Закону Головне юридичне управління Апарату Верховної Ради України в зауваженнях зазначило, що положення ст. $597^{8}$ ЦК України, зокрема, потребує уточнення «письмового повідомлення ... про намір укласти договip» [5].

3 огляду на вищевикладене, убачається за необхідне передбачити в ч. 1 ст. $597^{8}$ ЦК України більший строк для повідомлення боржника, користувача та довірчого засновника про намір довірчого власника укласти договір купівлі-продажу об'єкта довірчої власності. Ми вважаємо, що встановлення двомісячного строку буде достатнім для врахування прав та інтересів кожної зі сторін договору про встановлення довірчої власності й основного договору. У зв'язку з цим пропонуємо викласти ч. 1 ст. $597^{8}$ ЦК України в такій редакції: «Якщо інше не визначено договором про встановлення довірчої власності, звернення стягнення на об'єкт довірчої власності відбувається шляхом його продажу довірчим власником будь-якій особіпокупцеві. Довірчий власник зобов'язаний не пізніше ніж за два місяці до укладення договору купівлі-продажу письмово повідомити боржника, користувача та довірчого засновника про свій намір укласти цей договір і мінімальну ціну продажу. У разі невиконання зазначеної вимоги довірчий власник зобов'язаний відшкодувати таким особам завдані збитки».

Крім того, для досягнення балансу інтересів кредитора та боржника й-забезпечення боржнику (користувачеві, довірчому засновнику) можливості придбати об'єкт довірчої власності й унести кошти на депозит нотаріуса, пропонуємо внести зміни до ч. 2 ст. $597^{8}$ ЦК України, збільшивши строк для придбання боржником (користувачем, довірчим засновником) об'єкта довірчої власності та внесення коштів у розмірі мінімальної ціни продажу такого об'єкта на депозит нотаріуса, установивши місячний строк для повідомлення довірчого власника про намір боржника (користувача, довірчого засновника) придбати майно, передане в довірчу власність, якщо об'єктом довірчої власності $€$ нерухоме майно, і 10 днів, якщо об'єктом довірчої власності є рухоме майно.
Загалом, аналізуючи передбачену чинним цивільним законодавством процедуру звернення стягнення на об'єкт довірчої власності, можна стверджувати про наявність очевидного порушення балансу інтересів між учасниками цих правовідносин. Кредитор, який у такому випадку є довірчим власником, має істотні переваги над довірчим засновником, який водночас є боржником. Боржник, який є довірителем, є менш захищеним учасником порівняно 3 кредитором. Крім того, наявні в параграфі 8 глави 49 ЦК України механізми не передбачають суттевих обмежень для кредиторів у контексті забезпечення прав боржників. До того ж кредитор має потенційну можливість для зловживання своїми правами.

Не можемо не погодитися з К.Г. Некіт, яка зазначає, що «для того, щоб використовувати довірчу власність як спосіб забезпечення виконання зобов'язань, треба для початку чітко визначити сутність цього правового явища та закріпити його належне правове регулювання на рівні ЦК України» [6, c. 81].

Зважаючи на недосконалість законодавчого регулювання правовідносин довірчої власності, зокрема питань, пов'язаних зі зверненням стягнення на майно, передане в довірчу власність, можемо констатувати, що застосування довірчої власності в тому вигляді, у якому вона станом на сьогодні передбачена ЦК України, може призвести до того, що кредитори, особливо банки, будуть постійно використовувати довірчу власність як спосіб забезпечення виконання кредитних зобов'язань замість механізму застави або іпотеки, спонукати укласти договір про встановлення довірчої власності, відмовляючи у видачі кредитів чи наданні позики на підставі застави або іпотеки. Як наслідок, використання довірчої власності може скоротитися у зв'язку з тим, що боржник не буде впевнений у можливості збереження власного майна. Крім того, у разі виникнення фінансових труднощів у боржників кредитори, особливо банки, уникатимуть дій щодо сприяння своїм боржникам і навмисно відмовлятимуть їм у реструктуризації боргів, зокрема кредитів.

\section{Висновки}

Підсумовуючи вищевикладене, можемо констатувати наявність очевидного та істотного порушення балансу інтересів довірчого засновника, який водночас є боржником за основним зобов'язанням, порівняно $з$ довірчим власником як кредитором за основним зобов'язанням. Процедура звернення стягнення на об’єкт довірчої власності 
потребує суттєвого доопрацювання положень чинного цивільного законодавства 3 метою недопущення зловживання кредитором своїми правами. Незважаючи на складність забезпечення в цивільному законодавстві справжнього балансу інтересів обох сторін правовідносин довірчої власності, необхідно внести зміни до ЦК України, які його гарантуватимуть.

\section{Список використаних джерел:}

1. Цивільний кодекс України : Закон України від 16.01.2003 № 435-IV (зі змінами та доповненнями станом на 01.01.2021 p.). URL: https:// zakon.rada.gov.ua/laws/show/435-15\#Text.

2. Манжосова О.В. Особливості існування правового інституту довірчої власності в законодавстві України. Вісник Чернівецького факультету Наиіонального університету «Одеська юридична академія». Чернівці, 2014. Вип. 2. С. 145-154.

3. Про внесення змін до деяких законодавчих актів України щодо стимулювання інвестиційної діяльності в Україні : Закон України від 20.09.2019 № 132-IX. Відомості Верховної Ради Украйни. 2019. № 46. Ст. 299 .

4. Висновок Головного науково-експертного управління Апарату Верховної Ради України від 06.09.2019 на Проект Закону України «Про внесення змін до деяких законодавчих актів України щодо стимулювання інвестиційної діяльності в Україні» від 29.08.2019 № 1059. URL: https:// w1.c1.rada.gov.ua/pls/zweb2/webproc34?id=\&pf35 $11=66289 \& \mathrm{pf} 35401=497919$

5. Зауваження Головного юридичного управління Апарату Верховної Ради України від 20.09.2019 до Проекту Закону України «Про внесення змін до деяких законодавчих актів України щодо стимулювання інвестиційної діяльності в Україні» від 29.08.2019 № 1059. URL: https:// w1.c1.rada.gov.ua/pls/zweb2/webproc34?id=\&pf35 $11=66289 \&$ pf35401 $=501231$

6. Некіт К.Г. Довірча власність як спосіб забезпечення виконання зобов'язань: аналіз вітчизняного та зарубіжного законодавств. Часопис иивілістики. Одеса, 2016. Вип. 21. С. 78-81.

Anhelina Khodyrieva. Execution upon trust property: individual issues

The article is devoted to the study of the issue of the enforcement of the assets transferred to trust property. The emphasis is placed on the imperfection of the content of legal norms that regulate the procedure of the enforcement on the subject of trust property, which has led to problems of both scientific and practical nature, which continue to remain unresolved.

The theoretical and practical problems of the enforcement of the assets transferred to trust property are investigated. The provisions of the current civil law, which regulates the procedure of the enforcement on the subject of trust property, are analyzed in detail. The gaps in civil law related to the enforcement of the assets transferred to trust property are highlighted. The legislative approach to the formulation "the enforcement on the subject of trust property" is criticized. The emphasis is placed on the non-compliance with the basic principles of civil law of the deadlines set by the legislator of the enforcement on the subject of trust property.

The purpose of using such a method of securing the performance of obligations as trust property is justified. The emphasis is placed on the imperfection of the procedure provided by civil law of the enforcement on the subject of trust property. Attention is drawn to the significant violation of the balance of interests of the parties in the legal relations of trust property. Particular attention is paid to the problems of achieving and maintaining a balance of interests between the trustor and the trustee, the creditor and the debtor. It also analyzes the problems that creditors will face in case of the enforcement of the assets transferred to trust property, in case of other methods of securing the performance of obligations - such as collateral and mortgage.

It is concluded that the legal regulation of the procedure of the enforcement on the subject of trust property requires further legislative improvement. Proposals have been developed to amend the current civil law, which regulates the issue of the enforcement of the assets transferred to trust property.

Key words: trust property, legal relations of trust property, method of securing the performance of obligations, trustor, trustee, trust agreement, purchase contract, creditor, debtor. 